\title{
TRANSFERRIN COUPLED AZANTHRAQUINONE ENHANCES THE KILLING EFFECT ON TRYPANOSOMES. THE ROLE OF LYSOSOMAL MANNOSIDASE
}

\author{
NOK A.J.* \& NOCK I.H.**
}

\begin{abstract}
Summary :
Partially purified azanthraquinone (AQ) extract from Mitracarpus scaber was coupled to bovine transferrin (Tf) using azidophenyl glyoxal (APG). The AQ-APG-Tf conjugate was found to possess an enhanced in vitro trypanocidal activity against Trypanosoma congolense and T. brucei brucei. At low concentrations of 0.39 $90 \mathrm{mg} / \mathrm{ml}$, the conjugate diminished the growth of $T$. congolense and $T$. b. brucei dose dependently at the logarithmic phase. Both parasites were more sensitive to AQ-APG-Tf than to the free $(A Q)$ extract. Growth inhibition on the parasites by the free extract was observed at $20-200 \mathrm{mg} / \mathrm{ml}$. The total activity of the lysosomal enzyme a-mannosidase was reduced in the $T$. congolense cells treated with $A Q-A P G-T f$ in a dose related pattern. However, the activity of the mannosidase in the T. b. brucei treated cells is less affected. The AQ-APG-Tf is more effective on a mannosidase than free $A Q$, eight and four fold for $T$. congolense and $T$. b. brucei respectively. The results are discussed as regards the potency of using transferrin as suitable drug carrier in the chemotherapy of Human sleeping sickness.
\end{abstract}

KEY WORDS : azanthraquinone, transferrin, Trypanosoma congolense.
Résumé : AUgmentation de l'EFFET TRYPANOCIDE DE L'AZANTHRAQUINONE ASSOCIÉE À UNE TRANSFERRINE. RÔLE D'UNE MANNOSIDASE LYSOSOMIALE

L'azanthraquinone (AQ) partiellement purifiée, extraite de Mitracarpus scaber, a été associée à une tranferrine (Tf) d'origine bovine à l'aide d'azidophenyl glyoxal (APG). Le conjugué $A Q-$ APG-Tf est connu pour accroître in vitro l'activité trypanocide de I'AQ envers Trypanosoma congolense et $\mathrm{T}$. brucei brucei. A basse concentration $(0,30-90 \mu \mathrm{g} / \mathrm{m} /$ ), le conjugué diminue la croissance de T. congolense et de T. b. brucei de façon logarithmique dose dépendante. Les deux parasites sont plus sensibles à l'association $A Q-A P G-T f$ qu'à l'extrait libre d'AQ. L'inhibition de la croissance des parasites par l'extrait libre est observée entre 20 et $200 \mathrm{\mu g} / \mathrm{ml}$. L'activité de l'enzyme lysosomiale $\alpha$-mannosidase a été réduite de façon dose dépendante dans les cellules de $T$. congolense soumises à $A Q-A P G-T f$. Cette activité est moindre chez T. b. brucei. L'association AQ-APG-Tf est plus effective sur l' $\alpha$-mannosidase que l'extrait libre d'AQ, respectivement huit et quatre fois plus pour $\mathrm{T}$. congolense et $\mathrm{T}$. b. brucei. Les résultats sont discutés au regard de la possibilité d'associer la transferrine à la chimiothérapie de la maladie du sommeil.

MOTS CLÉS : azanthraquinone, transferrine, Trypanosoma congolense.

et al., 1993). Also fewer drugs are available for the treatment of chronic trypanosomiasis (Gutteridge, 1985)

Trypanosomes require transferrin for growth (Schell et al., 1996a, 1996b) and require it in a receptor-mediated fashion (Coppens et al., 1987; Webster \& Grab, 1988). In contrast to the mammalian cells, Tf and its receptor is delivered into African trypanosomes and may not be recycled (Grab et al., 1992, 1993). On account of the foregoing, it implies that with precise $\mathrm{Tf} / \mathrm{drug}$ combinations, it is possible to selectively kill the parasite by directing the drug to the trypanosome lysosome, living the mammalian cell unaffected. The inherent difficulty at raising vaccines against trypanosomes, due to the phenomenon of variable surface glycoprotein (VSG) has made the glycosyl phosphatidyl inositol (GPI) anchor a more appealing target in drug development.

In the present paper, the enhanced trypanocidal effect of AQ-APG-Tf and the possible interference with the synthesis of GPI synthesis of the trypanosome parasite is reported.

\footnotetext{
* Departments of Biochemistry and ** Biological sciences, Ahmadu Bello University, Zaria, Nigeria.

Correspondence: Andrew J. Nok.

E-mail: jandrew@skannet.com
}

Abbreviations: AQ, azanthraquinone; Tf, transferrin; APG, azidophenyl glyoxal. 


\section{MATERIALS AND METHODS}

B ovine transferrin, azidophenyl glyoxal (APG), Sephadex G25, para-nitrophenyl- $\beta$-D-mannopyranoside (pNP-man) were purchased from Sigma Chemical Company St-Louis, USA. General laboratory and inorganic chemicals were obtained from Wako, Japan.

\section{TRYPANOSOMES}

A stabilate of Trypanosoma congolense stb 212 and T. brucei brucei stb 421 were supplied by the Department of Veterinary Parasitology, Ahmadu Bello University, Zaria, Nigeria.

\section{EXTRACTION OF ACTIVE COMPONENTS OF MITRACARPUS SCABER}

Mitracarpus scaber leaves were collected fresh from the Botanical garden of Ahmadu Bello University, Zaria, Nigeria. The leaves (800 g) was homogenized in $4 \mathrm{~L}$ of chilled $\mathrm{EtOH}$, filtered and condensed by vacuum evaporation.

The concentrate was partitioned between EtOAc and $\mathrm{H}_{2} \mathrm{O}$ and the EtOAc fractions that exhibited trypanocidal activity was further partitioned between $90 \%$ aqueous $\mathrm{MeOH}$ and $\mathrm{n}$-hexane. The final methanolic extract, which was homogenous on TLC, was reduced by evaporation yielding about $12 \mathrm{~g}$ of the active residue.

\section{ISOLATION OF ACTIVE COMPONENT}

About $10 \mathrm{~g}$ of the active residue was further chromatographed on silica gel column. Elution of the fractions was conducted using: n-hexane: EtOAc (10: 1-0.2) gradient system and EtOAc: MeOH (4: 1). Fractions of 100 $\mathrm{ml}$ were collected. They were pooled according to TLC analysis. The EtOAc: MeOH fractions (10: 1 and 10: 0.5) were combined and re-chromatographed with the same solvent system. The extract had the same Rf with standard AQ and appeared as dark spots after exposure to UV radiation.

\section{Preparation OF AQ-APG-TF}

Bovine apo Tf $(100 \mathrm{mg})$ was loaded with $\mathrm{Fe}^{3+}$ as described by Klausner et al. (1983). The $\mathrm{diFe}^{3+}$-Tf was passed through Sephadex G25 to separate free $\mathrm{Fe}^{3+}$. The $\mathrm{diFe}^{3+}$-Tf was reserved for coupling. The AQ extract from the preceding section was then added to the $\mathrm{diFe}^{3+}-\mathrm{Tf}$. Cross linking of the extract and $\mathrm{diFe}^{3+}-\mathrm{Tf}$ was done by dispensing about $100 \mathrm{mg}$ of the AQ in $0.5 \mathrm{ml} 100 \mathrm{mM}$

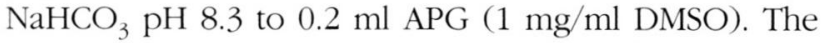
mixture was gently stirred in a volumetric flask covered with aluminum foil at $25^{\circ} \mathrm{C}$. This was followed by the addition of $1 \mathrm{ml}$ of diFe ${ }^{3+}$-Tf $(50 \mathrm{mg} / \mathrm{ml})$ in a buffer.

The transferrin was non-specifically linked with AQAPG complex by exposure to the sun for ten minutes.
The mixture was then centrifuged at 5,000 $\mathrm{g}$ for ten minutes and the recovered supernatant loaded onto Sephadex G25 to remove the unreacted AQ-APG fraction. The estimated AQ-APG-Transferin complex was $15 \mathrm{mg} \mathrm{AQ} / \mathrm{mg}$ protein.

\section{IN VITRO SENSITIVITY ON BLOOD STREAM TRYPANOSOME CONGOLENSE AND T. B. BRUCEI}

T. congolense and T. b. brucei were cultured in a 24 well culture plates at varying levels of AQ-APG-Tf $(0.04-100 \mu \mathrm{g} / \mathrm{ml})$ or AQ $(5-200 \mu \mathrm{g} / \mathrm{ml})$. The parasites were seeded at $4 \times 10^{5} / \mathrm{ml}$ in Dulbecco medium (GIBCO BRL) supplemented with $100 \mu \mathrm{M}$ hypoxanthine, $30 \mu \mathrm{M}$ thymidine, $40 \mu \mathrm{M}$ adenosine, $1 \mu \mathrm{M}$ sodium pyruvate, $50 \mu \mathrm{M}$ L-glutamine, $100 \mu \mathrm{M}$ 2-mercaptoethanol and $20 \% \mathrm{FCS}$, and incubated at $37^{\circ} \mathrm{C}$ under an atmosphere of $5 \% \mathrm{CO}_{2}$ and $95 \%$ air. The control culture was incubated without AQ and AQ-APG-Tf. Cell growth was screened based on motility and color change as described by Hirumi et al. (1993). In the system, live trypanosomes that grow well to stationary phase acidify the medium and change the color of the indicator dye phenol red from pink to yellow ( $\mathrm{pH}$ less than 6). The medium remains pinkish ( $\mathrm{pH} 7-8$ ) after three-five days incubation when the parasites are killed.

\section{ASSAY FOR $\alpha-1,2$ MANNOSIDASE ACTIVITY}

Both T. congolense and T. b. brucei that were treated with AQ-APG-Tf, AQ for one hour and the control (i.e untreated parasites) were separated from the medium by passing through DEAE cellulose column. The flow through fractions containing about $4 \times 10^{8}$ cells $/ \mathrm{ml}$ were spanned down at $5,000 \mathrm{~g} \times 5 \mathrm{~min}$. The parasites in each case were lysed in 50-mM acetate buffer $\mathrm{pH}$ 5.0. About $100 \mu \mathrm{g}$ of the crude lysate was incubated with $50 \mathrm{mM}$ of pNP-mannoside in $50 \mathrm{mM}$ acetate buffer $\mathrm{pH} 5.0$. At the end of one hour, the reaction was stopped using $0.1 \mathrm{ml}$ of $1 \mathrm{M} \mathrm{NaOH}$. The released para-nitro phenolate (pNP) ion hydrolyzed by the enzyme was determined at $540 \mathrm{~nm}$ using a spectrophotometer. One unit of $\alpha$-mannosidase activity was defined as that amount of enzyme that catalysed the release of $1 \mu$ mole of mannose from pNP-mannose per min per mg protein. Total protein of the parasite lysate was quantified as described by Lowry et al. (1951).

\section{RESULTS}

EFFECT OF AQ EXTRACT ON THE IN VTTRO GROWTH OF T. CONGOLENSE AND T. B. BRUCEI

$\mathrm{s}$ observed in Table I, the AQ extract at $25-$
$200 \mu \mathrm{g} / \mathrm{ml}$ inhibited the growth of both T. congo-
lense and T. brucei in a dose dependent pat- 


\begin{tabular}{ccc}
\hline & \multicolumn{2}{c}{ Cell growth (cells/ml) } \\
\cline { 2 - 3 } AQ $(\boldsymbol{\mu g} / \mathbf{m l})$ & T. congolense & T. b. brucei \\
\hline 200 & 0 & 0 \\
100 & 0 & 0 \\
50 & 0 & $10^{2} \pm 50$ \\
25 & 0 & $10^{4} \pm 10^{3}$ \\
12.5 & $10^{6} \pm 10^{3}$ & $10^{6} \pm 10^{2}$ \\
6.25 & $10^{6} \pm 10^{3}$ & $10^{6} \pm 10^{3}$ \\
\hline
\end{tabular}

Table I. - Trypanocidal activity of azanthraquinone extract (AQ) on T. congolense and T. b. bruce

The results are expressed as averages of the number of parasites in three experiments. The parasites were treated for $48 \mathrm{~h}$ with the respective level of the AQ. Only motile parasites were counted. At ' 0 ' the parasites were completely lysed.

tern. The minimum growth inhibitory level of the AQ extract was $25 \mu \mathrm{g} / \mathrm{ml}$ for T. congolense and T. b. brucei respectively. Below these levels of $\mathrm{AQ}$ for the respective parasites, there was no complete inhibition of growth on both parasites. However, they exhibited diminished motility as observed under phase contrast microscopy. Furthermore, when the parasites at $10^{5}$ cells/ml were sub-inoculated into healthy mice, they failed to elicit any parasitemia after 30 days after infection.

\section{EFFECT OF AQ-APG-TF ON BLOOD STREAM TRYPANOSOMES}

The coupled AQ-APG-Tf was incubated with either $T$. congolense or T. b. brucei. Both parasites were found to be highly sensitive to the growth inhibitory effects of the conjugate. As seen in Table II, at $0.39-100 \mu \mathrm{g} / \mathrm{ml}$, the conjugate inhibited the growth of $T$. congolense dose dependently within two days post incubation. The flagellic motility at less than $0.78 \mu \mathrm{g} / \mathrm{ml}$ of AQ-APG-

\begin{tabular}{ccc}
\hline & \multicolumn{2}{c}{$\%$ growth } \\
\cline { 2 - 3 } AQ-APG-Tf $(\boldsymbol{\mu g} / \mathbf{m l})$ & T. congolense & $T$. b. brucei \\
\hline 100 & 0 & 0 \\
50 & 10 & 5 \\
25 & 20 & 10 \\
12.5 & 40 & 15 \\
6.25 & 50 & 20 \\
3.12 & 60 & 50 \\
1.56 & 75 & 60 \\
0.78 & 80 & 65 \\
0.39 & 100 & 70 \\
0.19 & 100 & 85 \\
0.09 & 100 & 100 \\
\hline
\end{tabular}

Table II. - Trypanocidal activity of transferrin coupled methanolic extract of azanthraquinone (AQ-APG-Tf) on $T$. congolense and T. b. brucei

The results are expressed as averages of three experiments. Cell growth was measured after $48 \mathrm{~h}$ of incubation with the various amounts of AQ-APG-Tf.
Tf was very slow and the parasites appeared clustered. Also they were easily subdued when sub-inoculated into healthy mice. Similarly, the growth of $T . b$. brucei cells was inhibited by the AQ-APG-Tf conjugate. The minimal amount of AQ-APG-Tf required to inhibit T. b. brucei growth was $0.19 \mu \mathrm{g} / \mathrm{ml}$, i.e. about two to four folds more than that of $T$. congolense.

\section{EFFECTS OF AQ AND AQ-APG-TF ON} $\alpha$-MANNOSIDASE OF T. CONGOLENSE AND T. B. BRUCEI

The activity of acid $\alpha$-mannosidase from $T$. congolense and $T . b$. bruce $i$ were assayed after treatment with AQ and AQ-APG-Tf. A summary of the results is presented in Tables III \& IV. The level of $\alpha$-mannosidase activity in the control parasites (i.e. untreated) was 230 and $260 \mu \mathrm{mole} / \mathrm{min} / \mathrm{mg}$ for $T$. congolense and T. b. brucei respectively. The level of a-mannosidase activity diminished significantly for T. congolense when AQ-APGTf was used as the growth inhibitor (Table III).

The inhibition was clearly dose dependent with about $90 \%$ inhibition when $100 \mu \mathrm{g} / \mathrm{ml}$ of AQ-APG-Tf was used to inhibit growth. At $12.5 \mu \mathrm{g} / \mathrm{ml}$, about $50 \%$ of the activity was inhibited. The inhibition was not reversible even after dialysis suggesting strong covalent interaction between the conjugate AQ-APG-Tf and the enzyme. In contrast AQ-APG-Tf had a lower inhibitory effect on the activity of $\alpha$-mannosidase from $T . b$. brucei. The enzyme activity on both $T$. congolense and

\begin{tabular}{ccc}
\hline & \multicolumn{2}{c}{$\begin{array}{c}\boldsymbol{\alpha} \text {-mannosidase activity } \\
(\boldsymbol{\mu} \text { mole/min/mg) }\end{array}$} \\
\cline { 2 - 3 } AQ-APG-Tf $(\boldsymbol{\mu g} / \mathbf{m l})$ & T. congolense & T. b. brucei \\
\hline 100 & $18 \pm 8$ & $180 \pm 25$ \\
50 & $30 \pm 8$ & $195 \pm 20$ \\
25 & $43 \pm 15$ & $212 \pm 40$ \\
12.5 & $110 \pm 24$ & $201 \pm 35$ \\
6.25 & $180 \pm 20$ & $230 \pm 25$ \\
3.12 & $200 \pm 20$ & $235 \pm 40$ \\
0 & $230 \pm 30$ & $260 \pm 30$ \\
\hline
\end{tabular}

Table III. $-\alpha$-mannosidase activity in extracts of AQ-APG-Tf treated parasites. The results are expressed as averages of three experiments.

\begin{tabular}{|c|c|c|}
\hline \multirow[b]{2}{*}{$A Q(\mu \mathrm{g} / \mathrm{ml})$} & \multicolumn{2}{|c|}{$\begin{array}{c}\alpha \text {-mannosidase activity } \\
(\mu \mathrm{mole} / \mathrm{min} / \mathrm{mg})\end{array}$} \\
\hline & T. congolense & T. b. brucel \\
\hline 200 & $85 \pm 15$ & $210 \pm 25$ \\
\hline 100 & $105 \pm 22$ & $210 \pm 30$ \\
\hline 50 & $180 \pm 40$ & $250 \pm 35$ \\
\hline 25 & $210 \pm 40$ & $260 \pm 40$ \\
\hline 0 & $218+30$ & $260 \pm 30$ \\
\hline
\end{tabular}

Table IV. - Effect of azanthraquinone extract (AQ) on T. congolense and T. b. brucei.

The results are expressed as averages of three experiments. 
T. b. brucei were unchanged as compared with the control when the free AQ was used to inhibit growth (Table IV).

\section{DISCUSSION}

$\mathrm{H}$ ere, we report for the first time the trypanocidal activity of a carrier complex AQ-APG-Tf conjugate. In the present work we have demonstrated the feasibility of binding the AQ extract with transferrin using APG. The conjugate had a higher trypanocidal activity than free AQ. This observation suggests that the AQ-APG-Tf mediated trypanocidal effect is synergistic and construe the involvement of more than a target. This is reinforced by the fact that though the free AQ was growth inhibitory to both parasites, only the AQ-APG-Tf had a greater effect on the parasites' $\alpha$-mannosidase.

Furthermore, the effect on the enzyme was exclusive with the more susceptible $T$. congolense loosing about $50 \%$ of the a-mannosidase activity in the presence of $12.5 \mu \mathrm{g} / \mathrm{ml}$ of AQ-APG-Tf. The T. b. brucei $\alpha$-mannosidase was less responsive to the presence of the conjugate. The enhanced susceptibility thus suggests that the conjugate is delivered through a special system. Previous reports have shown that unlike the mammalian cell, in the acidic environment of trypanosome endosome system, serum transferrin along with its receptor is delivered to lysosomes (Mbawa et al., 1992). This essentially suggests that trypanosomes have evolved a modified mechanism for iron uptake. (Grab et al., 1992, 1993) previously proposed that since transferrin is delivered to lysosomes in African trypanosome, it might be possible to covalently bind drugs with plant or bacterial toxins to transferrin for use as chemotherapeutic agent.

Also, Shin et al. (1995) reported that transferrin can be used as targeting moiety for molecules across the blood brain barrier presumably through and interaction with Tf receptors in brain endothelial cells. Since Tf and lowdensity lipoprotein (LDL) particles enter the cell through receptor mediated endocytosis, a receptor-associated transport of AQ-APG-Tf conjugate to the lysosomal compartment of the parasite is contemplated.

Both T. congolense and T. b. brucei were sensitive albeit to a different extent to the conjugate. This could imply that the mechanism by which the parasites handle the AQ-APG-Tf in both systems could be different. Moreover, the sensitivity of the T. congolense $\alpha$-mannosidases and the attendant comparative insensitivity by the $T . b$. brucei enzyme supports this observation. The decreased a-mannosidase activity in the treated cells could be due to irreversible inhibition or repression in the synthesis of the enzyme. In support of the foregoing, Gerrits et al. (1996) reported that T. b. brucei has mul- tiple expression sites encoding for different mammalian Tf receptors, which allow trypanosomes to efficiently, take up Tf from a wide range of host. The T. congolense stb 212 used in the present study was maintained in a culture media with bovine serum presupposing that the receptors for Tf-bovine are expressed. On the other hand, the T. b. brucei was grown in Balb-c mice suggesting that the parasites could have adjusted to the expression of mouse specific Tf receptors.

The enzyme $\alpha$-mannosidase is a lysosomal enzyme especially with its $\mathrm{pH}$ optimum. It has been described in T. cruzi and T. rangelli (Alison et al., 1998; Nok et al., 2000). Our report is the first to show the presence of the enzyme in the African trypanosomes: T. congolense and T. $b$. brucei. The importance of $\alpha$-mannosidase in the processing system of glycoproteins in higher cells is well known (Alison et al., 1998). In mammalian cells, $\alpha-1,2$ mannosidase play an essential role in early steps of $\mathrm{N}$-linked oligosaccharide maturation. It could also serve the parasites in reprocessing derived oligosaccharides portion of glycoprotein to be mobilized in the synthesis of the GPI anchor.

From the observed results, AQ treated parasites had there enzymes unaffected by the plant extract. However, the tranferrin-coupled extract had a clear suppression on the activity of a-mannosidase by at least $30 \%$. Since the a-mannosidase is a lysosomal enzyme, its fall in activity implies a successful delivery of the extract to the lysosome. The compromised activity will have a far-reaching effect in the process of mobilizing the mannosyl residues by the parasite. Apart from preventing the association of the parasite with the host cells, the action of AQ-APG-Tf could induce the susceptible parasite to produce defective oligosaccharides, rich in mannose. Comparatively, there was no effect on the T. brucei enzyme which could be rationalized on the possible presence of other forms of receptors in T. brucei.

The summation of the observation shows that the drug delivery system with Tf is host specific. Our work clearly showed that transferrin has high potential for application in drug delivery system with enhanced trypanocidal effect. Furthermore, that at least an enzyme system involved in reprocessing glycoproteins is affected by the drug-conjugate strongly implies the possibility of targeting GPI synthesis. Results from this work should stimulate interest in the design of trypanocide-host specific Tf carrier systems for the assessment of different forms of trypanocide and their effect on the enzymes involved in GPI synthesis.

\section{ACKNOWLEDGEMENTS}

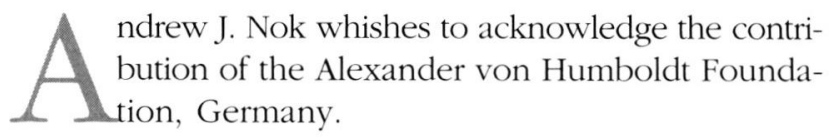




\section{REFERENCES}

Alison S., Vandersall N., Roberto K.M., O'Brien K.,Thomas N.O. \& Kelly V.O. Cloning expression purification and characterization of acid mannosidase from T. cruzi. Glycobiology, 1998, 8, 1183-1194.

Coppens I., Opperdoes F.R., Courtoy P.S. \& Baudhuin. Receptor mediate endocytosis of transferrin across blood brain barrier. Journal of Neuroscience Research, 1987, 18, 299-304.

Gerrits H., Bitter W., Kleft R. \& Borst P. Variation on T. brucei transferrin receptor and its function in host specificity. In: Molecular Parasitology Meeting VII, Goldberg D., Parsons M. \& Ullu E. Eds, Marine Biological Laboratories. Wood Hole, MA, 1996, p. 12.

Grab D.S., Well C.W., Shaw M.K., Webster P. \& Russo D.C.W. Endocytosed transferrin in African trypanosomes is delivered to lysosomes and may not be recycled. European Journal of Cell Biology, 1992, 59, 398-404.

Grab D.S., Shaw M.K., Well C.W., Webster P., Vergee Y., Russo D.C.W., NaEssens J. \& FISH W.R. The transferrin receptor in African trypanosomes. Identification, partial characterization and subcellular localization. European Journal of Cell Biology, 1993, 62, 114-126.

GutTERIDGE W.E. Existing chemotherapy and its Limitations. British Medical Bulletin, 1985, 41, 62-168.

Hirumi H., Hirumi K. \& Peregrine A.S. Axenic culture of T. congolense: application to the detection of sensitivity levels of blood stream trypamastigotes to diminazine aceturate, homidium chloride, isometamidium chloride and quinapyramine sulfate. Journal of Protozoology Research, 1993, 3, 52-63.

Klausner R.D., Van Renswoude J., Aswel G., Kempf C., SChEChter A.N., DeAn A. \& Bridges K.R. Receptor mediated endocytosis of transferrin in K562 cells. Journal of Biological Chemistry, 1983, 288, 4715-4724.

Lowry O.H, Rosebrough N.S., Farr A.L. \& Randall R.J. Protein measurement with folin phenol reagent. Journal of Biological Chemistry, 1951, 193, 265-275.

Mbawa Z.R., Gum I.D., Shaw E. \& Lonsdale Eccles J.D. Characterization of cystein protease from blood stream forms of T. congolense. European Journal Biochemistry, 1992 , 204, 371-379.

Nok A.J., Esievo. K.A.N., Longdet I., Arowosafe S., Onyenekwe P.C., GimBa C.E. \& KagBu J.A. Trypanocidal potential of Azadiracta indica: in vivo effect of leaf extract against Trypanosoma brucei. Journal of Clinical Biochemistry and Nutrition, 1993, 15, 113-118.

Nok A.J, Shuaibu M.N., Yanagi H. \& kanbara H. Purification and partial characterization of a mannosidase from T. rangelli. Parasitology Research, 2000, 86, 923-928.

Schell D., Borawy N.K. \& Overath P. Transferrin is a growth factor for blood stream forms of T. brucei. Parasitology Research. 1996, 77, 558-560.

Schell D., Evers R., Preis D., Ziegelbauer K., Kiefer H., LottsPeich F., Cornelissen A.W.C.A. \& Overath P. A transferrin binding protein in $T$. brucei is encoded by one of the genes in variant surface glycoprotein gene expression site. European Molecular Biology Journal, 1996, 10, 1061-1066.
Shin S.U., Frieden P., Moran M., Olsaon T., Kany Y.S., PADRIDGE W.M. \& Morison S.L. Transferrin antibody fusion proteins are effective in brain targeting. Proceedings of National Academy of Science USA, 1995, 92, 2820-2824.

STANFORD E.E. \& DAVY E.D. Alkaloid content of Datura affected by mosaic injury. Science, 1983, 58, 450-451.

Tropical Disease Research, $7^{\text {th }}$ Program Report, 1 January 198331 December 1984. Chap 5, 3-19 (UNDP Program/World bank/WHO).

Webster P. \& GRAB D.S. Intracellular localization of variant surface glycoprotein and transferrin-gold in $T$. brucei. Journal of Cell Biology, 1988, 106, 279-288.

Reçu le 7 mars 2002 Accepté le 4 juillet 2002 